\title{
Popularity of India's Regional Comic Strips: A Study of the Stylistics of Narayan Debnath's works
}

\author{
Rima Namhata, PhD \\ Jaipuria Institute of Management, Jaipur, Rajasthan, India \\ ORCID id: orcid.org/oooo-0oo2-9108-9519 \\ Contact: rimanamhata@gmail.com
}

\begin{abstract}
Though celebrated amongst the western literati and the intelligentsia thereof, Comic strips, especially the Indian produce with regional flavours in them, are seemingly juxtaposed, in the acceptance of their stylistic essence, if placed next to their western counterparts. This is also the reason why they have been infamously disregarded in the Indian academia. This paper proposes to study the stylistics aspect of the comic strips from Bengal especially the ones written by Shri Narayan Debnath, and the coming into vogue of this printed visual medium. This article aims to identify the uniqueness and the formal aspects of the stylistics of Indian Comic tradition from Bengal. Additionally, it aims to leaf through the popularity markers through Debnath's stylistics aspect of the three comic strips that have kept the imagination of his audience alive for more than five decades. He successfully addressed the first objective through a systematic literary review with inclusion and exclusion set as a benchmark. The identification of the stylistics through close reading of the texts along with their systematic review of secondary literature, formed the basics of the second objective. Particularly those stylistics were considered which were typical of their prominence and were integral across the literature and the texts. Furthermore, a matrix was also successfully designed to map the identified stylistics. A couple of implications portray that the said interpretation may help the Post-Millennials or the Generation $\mathrm{Z}$ to examine and consider the sublimity and allegiance of reading, and shape the imagination prowess of young minds, apply their intellectual faculty and develop a comic disposition in life. Development of creativity in any narrative style and development of conversational mechanisms are often found to be an added bonus. However, making today's generation read this form of narrative and chisel their fertile imagination remains a challenge for the digital-natives. There is no doubt however, that this age-old art form can be tremendously advantageous as an academic endeavour and become an integral part of children's systematic reading habit.
\end{abstract}

Keywords: Bengal comics, stylistics, conversation mechanics, children’s literature, Narayan Debnath

\section{Introduction}

A popular internet search engine is capable of zooming into the words 'Indian Comic strips' and throw back 8680 results in less than 0.21 seconds. As perplexity dawned in, leading to a state of entangled curiosity, I ended up looking more into it, hoping to find the source of it's true potential and that is how I chanced upon the fact that comics in India exists not only superficially but has its roots spread deep and wide, in the minds of the youngsters, who reserve a special relation with their comic books, even in the age of x-box. Though comic books in India have a loyal fan-base and a gigantic readership potential, yet it comes with the baggage of an insignificant academic scholarship. Hoping to learn further, my inquisitive mind probed deeper to find out about how the

(C) AesthetixMS 2021. This Open Access article is published under a Creative Commons Attribution Non-Commercial 4.0 International License (http://creativecommons.org/licenses/by-nc/4.o/), which permits non-commercial re-use, distribution, and reproduction in any medium, provided the original work is properly cited. For citation use the DOI. For commercial re-use, please contact editor@rupkatha.com. 
words 'cartoon', 'comics' 'graphic novels' and 'webcomics' are used interchangeably today. In the context of this paper, it necessitates distinguishing the terminologies from the existing literature.

'Comics' is known to have its origin around the late $16^{\text {th }}$-century loan Latin to Greek word, kōmikos, to kōmos that is 'revel'; an event that brings amusement or festivity, as is already popularly known about the famous Greek comedy plays. OED ${ }^{1}$ defines Comics as a periodical having serialised comic strips intended mostly for children. It can also be "a series of small drawings, called frames, with words that tell a story ... Most comic strips make jokes about the characters in them and the things that happen to them." Interestingly, Comics are also image-texts [Kumar, 2008]. Literature suggests it may have an element of socio-cultural background to it. The other term Cartoon is defined by $O E D$, as a "humorous drawing in a newspaper or magazine, especially one about politics or events in the news." Furthermore, Cartoons can also be sub-divided as animated films or movie adaptations. The third category, Graphic novels, is quite a later addition in the genre category writings. These are novels with illustrations with a plot, character, theme and characteristics integral to the novel. A Graphic novel, in "American and British usage [is] a type of text combining words and images-essentially a comic, although the term most commonly refers to a complete story presented as a book rather than a periodical". It also adds to "a long comic narrative for a mature audience, published in hardback or paperback and sold in bookstores, with serious literary themes and sophisticated artwork" [Hasan, 2009]. Finally, a newly added label, Webcomics has not found entry in $O E D$, although the Random House dictionary defines it as "an online comic strip or cartoon, especially one that was originally published online” [ uchicago.edu].

\section{Scope}

Since Indian Comics has a limited academic scholarship, there are unchartered territories within this medium. However, some vernacular pockets of Indian Comics have escaped the attention of reviewers and academic literature. It refers to the ones that emerged from West Bengal that reveal how this printed visual medium rose to popularity. It was in 2001, with the initiative of Udoyan Bhattacharya, the first teleserial came with the Handa-Bhonda episodes. The next exalted visibility came in 2002, which was Sandipan Burman's directed 'Nonte-Phonte' series. The animation of Bantul and Handa-Bhonda series was done by Ajay Sensharma, and Nonte-Phonte by Sourav Mondal. Popularity escalated to 2 lakh readers for Handa-Bhonda series by 1982 [Ghosh and Deb, 2013]. Also, the stories of Nonte Fonter Nanan Kirtee became an animated television series and was aired in Akash Bangla since 2006 and it became a huge success both commercially and critically. Further, 'Bantul the Great' found its way through Greetings Card imprints by 'Smarnika' from Phariyapukur [Ghosh and Deb, 2013]. Surprisingly, in the face of such popularity, the literature on Bengal's comic strip contribution is trivial.

This paper opens the scope to study the unchartered territories of Bengal's (regional) contribution to this vernacular medium and the journey since its inception to the current times. The evolutionary journey of the select comic strips is encapsulated in Table 1.

1 OED: Oxford English Dictionary 
Table 1. Evolutionary journey of Narayan Debnath's select comic strips

\begin{tabular}{|c|c|c|c|c|}
\hline Texts & $\begin{array}{c}\text { Bengali calendar to } \\
\text { Georgian calendar }\end{array}$ & Magazine & Major characters & $\begin{array}{c}\text { Publication } \\
\text { House }\end{array}$ \\
\hline Bantul the Great & 1965 & Shuktara & Bantul & Debsahitya Kutir \\
\hline Handa-Bhonda & $1962-2012$ & $\begin{array}{c}\text { Shuktara, 'Hasir } \\
\text { Atom Bomb' }\end{array}$ & $\begin{array}{c}\text { Handaram } \\
\text { Gorgori, Bhonda } \\
\text { Pakrashi }\end{array}$ & Debsahitya Kutir \\
\hline $\begin{array}{c}\text { Nonte Phonte } \\
\text { Screen adaptation } \\
\text { to 'paribartan' }\end{array}$ & $\begin{array}{c}\text { December 1969- } \\
\text { continuing (100) }\end{array}$ & Kishore Bharati & Nonte and Phonte & Patrabharati \\
\hline
\end{tabular}

\section{Objective}

Questions arise, whether the popularity, long run and immense visibility of these comic strips have certain stylistics that captivated Bengal's youth imagination? Needless to say, readership across age groups and soaring popularity have to have some integral stylistics that captures the youth mind. This article aims to identify the unique stylistics and formal aspects of Indian Comic tradition from Bengal. It also aims to study the popularity markers through the stylistics aspect of Narayan Debnath's three comic strips that have kept audience imagination alive for more than 5 decades.

\section{Methodology}

To identify the stylistic aspects, a systematic literature review was conducted with inclusion and exclusion criteria. A computerised literature search was executed during September-October, 2020 in electronic databases of EBSCO, Elsevier, Taylor and Francis, and Cultural Studies Database of Stony Brook University using keyword Indian Comic Strips. The preliminary step identified 2396 works. However, articles meeting the following inclusion criteria were shortlisted: (a) written in English (b) published in peer-reviewed journals, and (c) conceptual and theoretical works exploring the comic tradition in India over the years. It brought mixed results after which only those articles contributing to India's comic tradition and pertaining relatively on stylistics were chosen. The number came to 97. Further websites, blogs, e-magazines fulfilling criteria (a) and (c) were also included. Articles that dealt with Graphic novels/narratives, caricatures, cartoons, webcomics, graphic computing were excluded. A total of 27 articles, 1 thesis, 2 books, 2 newspaper articles, 3 blogs, and 2 e-magazines was shortlisted. The shortlisted works were read systematically by the author to identify the stylistic and the formal aspects of the Indian Comic tradition. This was further corroborated by closely reading the Preface, intermittent notes, and the glossary of Narayan Debnath's Comics Samagra [Deb and Ghosh, 2013, p.10]. The common stylistics across Debnath's works were taken in consideration through Table 2.

The first objective has been addressed primarily by studying Narayan Debnath's three comic strips namely Bantul the Great (hence forth, BTG), Handa Bhonda, and Nonte Phonte series from 
Narayan Debnath's Comics- Samagra² (2013). I chose Narayan Debnath for being the recipient of the prestigious Sahitya Academi in 2013 for his Comics-Samagra in the category of 'Bal Sahitya puraskar' (Children's Literature). Yet, his works have hardly found literary and critical significance. The texts have been chosen through Purposeful sampling. Handa Bhonda series has remained unparalleled in holding the record for the longest-running comic strip (1962 to 2015, a huge 53 years), much to the likes of Johnny Hart's BC (49 years; 1958-2007) and Hank Ketchum's Dennis the Menace (43 years; 1951-1994). These three comic strips further feature as 'popular comics' categorised in the index page of Comics- Samagra [Ghosh and Deb, 2013]. Other than appearing in popular categories, they have found a place in screen adaptations. This makes it all the more relevant to study the comic series namely Bantul the Great, Handa Bhonda, and Nonte Phonte, legendary imaginative names in the household of Bengal's children.

To address the second objective, stylistics have been identified with close reading of the texts and systematic review of secondary literature. Only those stylistics were considered that were prominent and integral across the literature and the texts. A matrix has been designed to map the identified stylistics for this paper. It is a variant of content analysis, a framework arrived at inductively. Finally, content analysis is applied to systematically analyse the qualitative data. The matrix (Table 2) has the identified stylistics of Bengal Comic tradition marked across the horizontal axis or the columns of the table. The fictions $\left(\mathrm{T}_{1}, \mathrm{~T}_{2}\right.$, and $\left.\mathrm{T}_{3}\right)$ have been marked across the vertical axis or the rows. Textual analysis through close reading of the texts was carried out keeping in view the six stylistics marked across the columns. The identified stylistics are(characters), panel, tone (sub-divided into 1. Theatricality; 2. Colloquialism), speech balloon, colours used, and rhetorical devices (sub-divided into 1. Regional onomatopoeia; 2. Stuttering) that add to the readability and the popularity of these strips.

Table 1. Matrix mapping stylistics with select Bangla comic series

\begin{tabular}{|c|c|c|c|c|c|c|}
\hline \multirow[b]{3}{*}{ Texts } & Stylistics 1 & Stylistics 2 & Stylistics 3 & $\begin{array}{c}\text { Stylistics } \\
4\end{array}$ & $\begin{array}{c}\text { Stylistics } \\
5\end{array}$ & Stylistics 6 \\
\hline & \multirow[b]{2}{*}{ Characters } & \multirow[b]{2}{*}{ Panel/frame } & Tone & \multirow[b]{2}{*}{$\begin{array}{l}\text { Speech } \\
\text { balloon }\end{array}$} & \multirow[b]{2}{*}{$\begin{array}{l}\text { Colours } \\
\text { used }\end{array}$} & $\begin{array}{c}\text { Rhetorical } \\
\text { devices }\end{array}$ \\
\hline & & & $\begin{array}{l}\text { 1. Theatricality by } \\
\text { even use of light and } \\
\text { shade } \\
\text { 2. Use of } \\
\text { colloquialism } \\
\text { a. Use of Bangla } \\
\text { expletives to evoke } \\
\text { laughter } \\
\text { b. Bilingualism }\end{array}$ & & & $\begin{array}{l}\text { 1.Regional } \\
\text { Onomatopoeia } \\
\text { 2. stuttering }\end{array}$ \\
\hline $\begin{array}{l}\text { T1:Bantul the } \\
\text { Great }\end{array}$ & & & & & & \\
\hline
\end{tabular}

\footnotetext{
2 Samagra: a collection/ a compendium
} 


\begin{tabular}{|l|l|l|l|l|l|l|}
\hline $\begin{array}{l}\text { T2:Handa- } \\
\text { Bhonda }\end{array}$ & & & & & & \\
\hline $\begin{array}{l}\text { T3:Nonte } \\
\text { Phonte }\end{array}$ & & & & & & \\
\hline
\end{tabular}

The filled-up matrix has been appended as Appendix 4.

\section{Story-line}

The mapping and the findings of the matrix necessitate to briefly outline the story of the three comic strips.

a. Bantul the Great (1965): A comic strip in dual tone of orange and black where Bantul is a superhero modelled on the then Bengal's famous bodybuilder, Manohar Aich. The superpowers of Bantul were not granted until the Bangladesh war of liberation (IndoPakistan war of 1971) when the editors and the publishers wanted Bantul to be invincible. Bantul no sooner symbolised formidability. Bantul has God-like strength and his body acts like a bullet-proof frame. He is a messiah for the good people and a terror for the hooligans of society. Sometimes his formidable strength leads to the breakdown of machinery when he tries to operate it. [ Bantul the Great, Wikipedia]

b. Handa Bhonda (1962): A comic strip in grey-scale, has two major characters Handa and Bhonda. It is the story of two boys the slender (Handa) and the other bulky (Bhonda). Handa is always playing a foul trick to put aside others, and Bhonda in particular. The stories, however, conclude with Handa being punished for his mischievous tricks. Many say that Handa and Bhonda are inspired by the famous duo, Laurel and Hardy series.

c. Nonte Phonte (1969): A comic strip in grey-scale has its major characters by the title names, Nonte and Phonte, two boarding school students. The episodes begin from the hostel of the boarding school in the mofussil area of Paschimpara in West Bengal with the parallel characters being: the Headmaster, the superintendent and the staff. The characters have whimsical names that add to the amusement of the readers. Nonte and Phonte have a school senior by the name of Keltu who is a bully and malicious towards Nonte and phonte. He hatches foul tricks to belittle Nonte and phonte but ultimately gets reprimanded because of his actions. (Appendix 3)

\section{Synthesising the findings of the matrix}

The grammar of comic narrative has the interplay of visual and verbal and adds into the comic effect. Here, is a stylistics, a combination of both 'visual and verbal values', especially for comic strips [Saraceni, 2003]. It is worthy to mention that the comics especially, Bantul the Great has taken in account the social and the political context [Kundu, 2013], Selwood and Irwing [1993] of the then Bengal. Bantul is a heroic figure who evolved with time. Narayan Debnath's Bantul ('favourite child' 
by Debnath's admission) has his chest illustratively expanded and contracted with stick-thin legs in the strips from the years 1967,1980,1987, 2011 (Appendix 1). In Bangla, Bantul sarcastically means a short-statured person and here he is a superman with heroic powers that evokes quite some comicality. In one of the strips, he is shown to capture the visual appeal of crossing a river through a pole jump is hilarious and it shows a stupendous expression of sawing a long tree by his leg [10] ${ }^{3}$. In the Handa Bhonda series, the characters are of the same name and many consider it to be modelled on the legendary characters Laurel and Hardy! (Appendix 2) Finally, in the Nonte Phonte series, Nonte has longer hair with a hair tuft sticking out; Phonte has shorter crew-cut hair. In this series, they are always into mischief and either win a situation or get humiliated. The second stylistics, panels, have mostly 2 to 3 in all the strips that add to the 'graphic side of the readers' [18]. Framed conversations or the panels with the tropes of image-text and speech balloon dialogues often grip the readers' visual imagination. Stylistics 3 is speech balloon and is considered beyond the selection of words and spellings [Cohn, 2013] and are the specific signifying system of the cartoon and the comic. Rightly observes Kress and Leeuwen who see the bubble or balloon as representing a senser (thought) or a speaker (dialogue) [2006]. They are either spherical shaped or square with rounded edges in all the three comic strips. Also, anger is often depicted in large capitalised or bold font types as in G-R-R-R-R (a snarling dog) [25] and is part of typography. In comic dialogue, the visual effect is also enhanced by stylistics 4 which is the use of colours in the comics strips. It is bi-colour for all with the combinations being: red-black, white-black, and orange and white. The colour shades also add to the element of theatricality, the tone (stylistics 5) of this matrix. The tone is a prominent dimension of stylistics in comic narratives. The second identified characteristic of tone is the use of colloquialism. Reading closely the narratives, it is seen that the language has the flavour of a semi-urban setup, quite typical of Bengal's mofussil Bangla. Words like 'baatlechhis' (103), 'shokunimarka' meaning shrewd (121)4, 'saabre' (121, to eat greedily), pola (77), 'ganjachhe' (89, gossiping) are atypical colloquials of Bangla from the mofussil areas, and only indigenous Bengali readers can relate to it.

The unique characteristics of use of Bangla expletives evoke laughter in unparalleled ways, where the intent of the speaker is context-driven. Words like 'punchkke chhora', 'hotobhaga', 'morkot', 'hotochhara' (98) with which only Bengali speakers can relate to that how in each context none of them sound humiliating. Further, words like 'chhuncho' (meaning, Mole, 104), 'chhinchke' (small thief) also exuberate a tone of affection where these words have grown out of elder people for younger generations. On the contrary, it sounds funny as and when used by the characters. The other colloquial characteristic is the frequent use of bilingualism in dialogues that makes the conversation life-like and readers live the commonplace experience. Bilingual words like, 'dushman'(enemy), 'jawan'(soldier), 'pakro' (catch hold), 'bonechhi' (to become, compounding of Hindi 'bana' and Bangla 'hoyechhi') are prominent examples in BTG. Also, 'ghabrao mat' (do not fear is the combination of Bangla and English), 'radio shonar dafa gya' (days to hear radio are gone, is a combination of Bangla and Hindi) and 'pakrao kor' is also the same, catch hold. Young readers feel happy to find their characters being successful in their plans, however, Narayan Debnath weaves the storyline in a manner where young minds envisage the admiring defeat of the devils.

Stylistics 6, is rhetorical devices and integral to comic strips. Closely reading the texts identified two characteristics of such rhetorics: i. Regional onomatopoeia ii. Stuttering. These two

\footnotetext{
${ }^{3}$ The page numbers within brackets are taken from Ghosh, S. and Deb, D (2013). Narayan Debnath ComicsSamagra (Edited) First Volume. Lalmati Publishers.
} 
serve as a narrative function where "children[may] actively experiment with the representational resources of word and image...combined" explains Kress and van Leeuwen in Reading Images: The grammar of visual design (2006, p.113). Onomatopoeia, defined by Britannica is something where "the sound suggests the sense". To understand regional onomatopoeia, the three comic series have words like 'jhappath' (21, diving sound in water); 'Durrrum' (22, firing of canon); 'karaaaath' (23, breaking open the main entrance); 'ghonth-ghr-ghr-ghr-ghr, phonth-phr-phr-phr-phr' (33, snoring); 'grrrrrrr' (39, growling of a dog); 'chakum chukum' (44, sound of having a delicious dish); 'jhappashhhh' (104, falling into water pool); 'aafff, ufff' (105, the pain after being caned by school teacher.); and 'fararrrrrr phonth' (107, snoring). The vivid description evokes laughter as the images, sound and speech balloons combine to titillate the laughing glands. My observation is, subconsciously, for children to find adults being fearful, or falling or even slipping is something unexpected by the young minds and see a sense of comicality expressed through this rhetorical device.

The other feature of the rhetorical device is stuttering. Defining the term Franklin $\mathrm{H}$. Silverman in Stuttering and Other Fluency Disorders, explains it as "repetition of sounds and syllables and prolongation of speech sounds" [2003]. Scholars also suggest that "Stuttering that appears in literature often serves a comical function . . . characterized by representing the characteristics of this disorder designed to produce laughter" [Cabrera, 2001]. In BTG, expressions like 'tu-lchhi pi-pisemosai' (88, picking you uncle) come from the fear that Bhonda's uncle fell because of Bhonda's thoughtless act. In Nonte Phonte, fear also invades the mind of the character Nonte, where he stammers into ki-ki-kintu (122), meaning but.

Beyond the identified and integral stylistics, some other textual markers evoke laughter and have been prominent in keeping the popularity alive for these three comic strips. They are snide remarks with rhyming words. Also, behind the screen dialogue, (called 'Aside' in the concept of play) affect the laughing senses of the readers. The themes appealed to the generation of readers who saw the characters entrenched in nationalism especially the vagaries of Indo-Pakistan War of 1965. Narayan Debnath's attention to human figures especially the gap between two legs of the characters creates a hilarious human anatomy. Also, elderly and strict men are represented as bald and pot-bellied; when considered as a whole of image, text, panel, and space balloon, they add to the comicality.

\section{Implications of the study}

The steady loyalty of Debnath's classics has remained a household item in Bengal for several decades. This study may help the post-Millenials or the GenZ to relive the nostalgia of their parents and realise the beauty and loyalty of reading; especially children's literature that enchants to enter the trance of wonderland as Alice did. This may help in shaping the imagination prowess of youngsters, apply intelligent humour in life, develop creativity in writing style and even develop conversation mechanisms.

\section{Conclusion}

This paper playfully makes a serious attempt to teach comic literary tropes, stylistics, the rhetorical devices that are often integral to creative writing. Some of the stylistic aspects existed in the 
tradition of comic series, and on closer textual reading, some more evolved in the context of Debnath's works. Paying attention to comic strips other than the fun of reading may legitimise the claim that the genre is a 'significant cultural form' and its studies could be a 'legitimate academic endeavour' and not bolstered by 'just kids' stuff [Fawcett, 20018] in a larger reading context. Reconsidering how we read comics, the stylistics keep alive readers' imagination and the art forms. Reading as a growing-up process always help us to remember our fantasy and our creators, where passing on these art illustrations also need sincere effort. As an academic-practitioner and growing up with Debnath's illustrations, I reflectively would like to mention that though these comic illustrations were entrenched in nationalism and specific socio-cultural context of the 1960-70s decade, it needs to undergo a cultural change (thematic shifts) making it significant with the concurrent times. There has been sea change in Bengal's cultural landscape which the upcoming generations reading Debnath's works may not be able to relate with. So just not passing on the illustration techniques (stylistics), but redefining the cultural landscape by the torch-bearers of Debnath's works may make the works relatable, fun and continue capturing the popular imagination. Further, making today's digital natives read and chisel fertile imagination remains a challenge. Henceforth, regional comic strips especially Narayan Debnath's works which have received occasional literary recognition, can find mainstream identity either through school or college academia that may keep alive the popular imagination of children and adults alike.

\section{Acknowledgments}

An extended abstract of this paper was presented in ComIN2o Conference organised by the Department of Design, IIT Delhi, 2020. I received some insightful inputs and wish to acknowledge the conference convener for this. Further, I would like to acknowledge my friend, Ms. Srabani Mukherjee for reading the manuscript and helping me to make some minor changes.

\section{References}

Cabrera, A. (2001). Stuttering in Literary Arts. In https://www.mnsu.edu/comdis/isad4/papers/cabrera.html

Chakrabarty, A. (2016). A throwback to Indian Comics. In https://theculturetrip.com/asia/india/articles/athrowback-to-indian-comics/

Charbak, D. (2019). The worldof Narayan Debnath. In https://www.youthkiawaaz.com/2019/o4/the-worldof-narayan-debnath/

Cohn, N. (2013). Beyond Speech Balloons and Thought Bubbles: The Integration of Text and Image. Semiotica, pp. 35-63.

Deb, D. (2007, November 11). How Bantul Was Born: Debasish Deb meets Narayan Debnath the Cartoonist. The Telegraph.http://www.telegraphindia.com/1071111/asp/calcutta/story_8533502.asp

Eisner, W. (1996). Narrative and Graphic Storytelling. Poorhouse Press.

Bantul the Great(n.d.) In Wikipedia. https://en.wikipedia.org/wiki/Bantul_the_Great

Fawcett, C. (2018). The Routledge companion to comics. Journal of Graphic Novels and Comics. DOI: $10.1080 / 21504857.2018 .1437054$

Franklin, H. S. (2003). Stuttering and Other Fluency Disorders. Waveland Press, https://www.britannica.com/topic/onomatopoeia 
Ghosh, D. (2019). Meet Narayan Debnath, the grandfather of Bengali comics for six decades. https://scroll.in/article/934297/meet-narayan-debnath-the-grandfather-of-bengali-comics-for-sixdecades.

Ghosh, S. and Deb, D. (2013). Narayan Debnath Comics-Samagra. (Edited) First Volume. Lalmati Publishers. Hasan, M. (2009). Wit and Humour in Colonial North India. Niyogi Books.New Delhi.

Graphic Novel. https://lucian.uchicago.edu/blogs/mediatheory/keywords/graphic-novel/

Webcomic . https://lucian.uchicago.edu/blogs/mediatheory/keywords/webcomic/

https:/timesofindia.indiatimes.com/times-litfest-kolkata-2019/speakers/narayandebnath/articleshow/72402527.cms

Britannica. (n.d.). Graphic novel. In Britannica online Retrieved September, 30, from https://www.britannica.com/art/graphic-novel

Kress, G. and van Leeuwen, T. (2006). Reading Images. The Grammar of Visual Design. Routledge.

Kundu, M. (2012). Famous Three Musketeers of Narayan. http://manashsubhaditya.blogspot.com/2012/10/famous-three-musketeers-of-narayan.html

Kumar, A. (2008) Raj Comics for the Hard-Headed. Sarai Programme, Centre for the Study of Developing Societies. Delhi.

Miodrag, H. (2010.) Fragmented Text: The Spatial Arrangement of Words in Comics. International Journal of Comic Art 2(3), 309-327.

Orwell, G. (1946) Critical Essays, Seeker and Warburg.

Rao, A. (2001). From Self-Knowledge to Super Heroes: The Story of Indian Comics. In John A. Lent(Ed.), Illustrating Asia, Comics, Humour Magazines, and Picture Books (pp. 37-63.) Richmond.

Saraceni, M. (2003). The Language of Comics. Routledge, New York.

Selwood, S. and Irving, D. (1993). Harmful Publications: Comics, Education and Disenfranchised Young People. London, Art and Society.

Shome-Ray, A. (2013). https://www.dnaindia.com/lifestyle/report-handa-bhonda-creator-narayan-debnathgets-sahitya-akademi-award-a-look-at-the-life-and-works-of-the-comics-writer-1884322

Wes, R. (2018). Scripted voices: script's role in creating Japanese manga dialogue. Journal of Graphic Novels and Comics, DOI: 10.1080/21504857.2018.1431799 (2018)

Whitty, M. T. (2003). Cyber-Flirting: Playing at Love on the Internet. Theory \& Psychology 13 (3): 339-357. doi:10.1177/0959354303013003003. (2003)

Dr. Rima Namhata is serving as an Assistant Professor of Business Communication in Jaipuria Institute of Management, Jaipur. Her research areas include Indian Campus fiction, Discourse Analysis, pedagogical approaches to Soft Skills, Business Communication, and Sustainability practices over Language Awareness. 
Appendix 1: Representation form of Bantul in Bantul the Great over the years: 1967, 1980, 1987, 2011

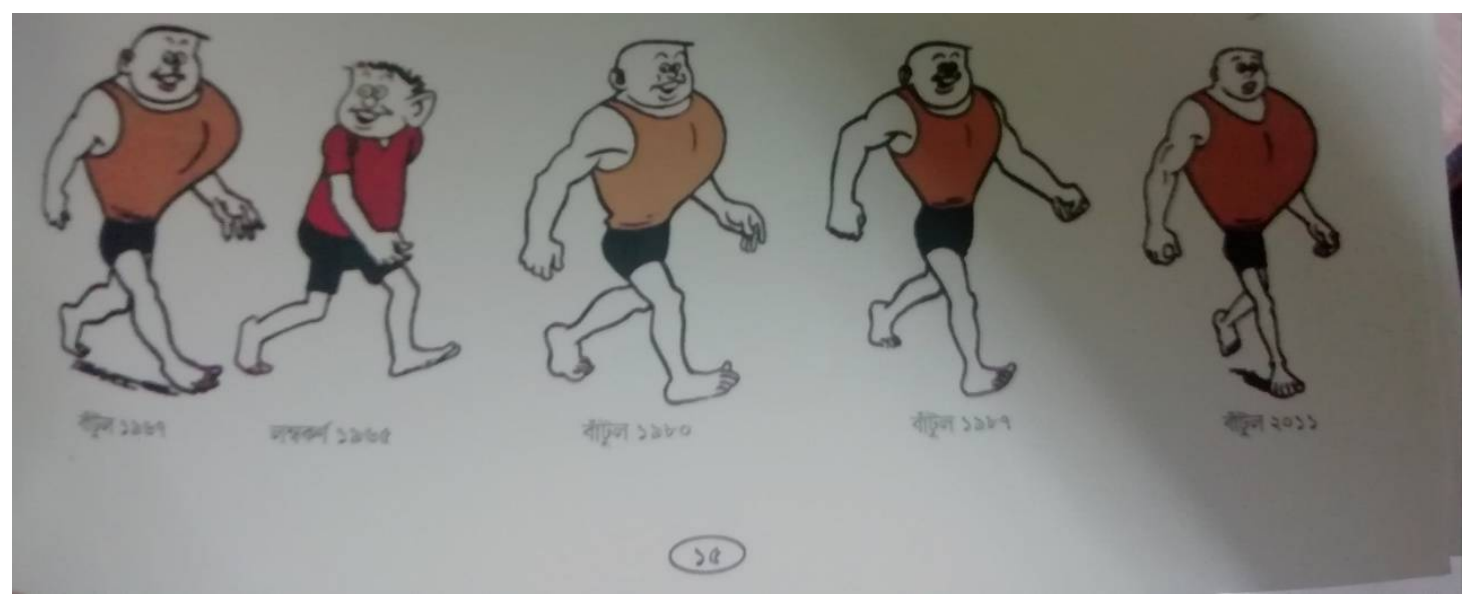

Source: Narayan Debnath's Comics Samagra , 2013 (1 ${ }^{\text {st }}$ Edition) [11]

Appendix 2: Cover page of Handa Bhonda comic series

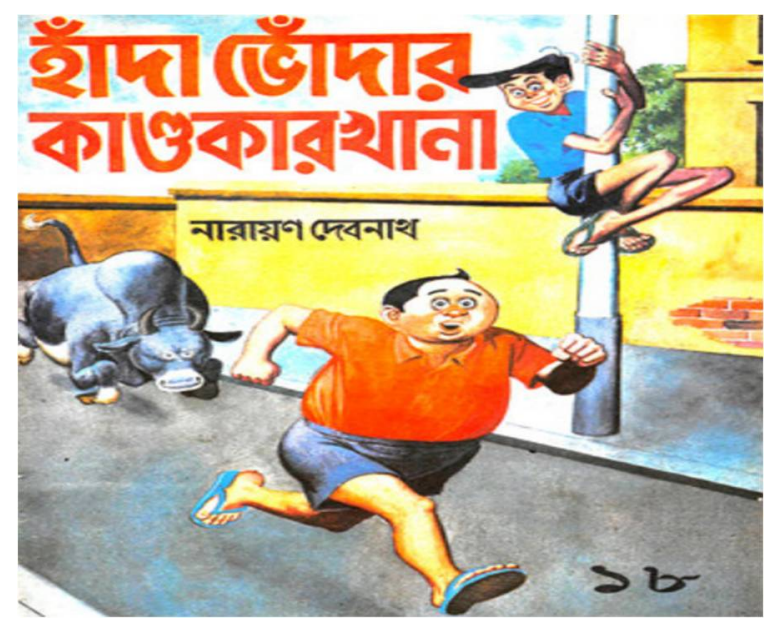

Source: https://scroll.in/article/934297/meet-narayan-debnath-the-grandfather-of-bengalicomics-for-six-decades [9] 


\begin{tabular}{|c|c|c|}
\hline $\begin{array}{l}\text { Speech } \\
\text { balloon }\end{array}$ & $\begin{array}{l}\text { Spherical } \\
\text { shaped; Square } \\
\text { with rounded } \\
\text { edges }\end{array}$ & ; \\
\hline $\begin{array}{l}\text { Colours } \\
\text { used }\end{array}$ & $\begin{array}{l}\text { Bi-colour (red } \\
\text { and black) }\end{array}$ & \\
\hline \multirow{2}{*}{$\begin{array}{c}\text { Rhetorical } \\
\text { devices }\end{array}$} & $\begin{array}{l}\text { 1.Regional } \\
\text { Onomatopoeia }\end{array}$ & \multirow{2}{*}{$\begin{array}{l}\text { 1. Jhappath (diving in water and the sound it makes (21); Durrrum } \\
\text { (firing of canon)(22) } \\
\text { Hu-sh-hh(3); ore-bas-s-s(18); karaaaath(breaking open the } \\
\text { main entrance (23); doom-doom; guuuruuum (24); darrram } \\
\text { (bursting out)(25); ghont-ghr-ghr-ghr-ghr, phont-phr-phr-phr- } \\
\text { phr(snoring)(33); grrrrrr(goowling of a dog)(39); chakum } \\
\text { chukum (bangla word to show how delicious a dish is)(44) }\end{array}$} \\
\hline & 2. stuttering & \\
\hline \multicolumn{3}{|r|}{ Text 2: Handa Bhonda } \\
\hline Stylistics & Characteristics & Excerpts with page numbers \\
\hline Characters & $\begin{array}{l}\text { Thin Handa, fat } \\
\text { Bhonda; Handa } \\
\text { has albot } \\
\text { hairdo }\end{array}$ & Inspired by the legendary characters Laurel and Hardy! \\
\hline Panel/Frame & $\begin{array}{l}\text { Mostly } 2 . \\
\text { Somewhere } 3\end{array}$ & Remains the same \\
\hline \multirow[t]{2}{*}{ Tone } & $\begin{array}{l}\text { 1.Theatricality } \\
\text { by even use of } \\
\text { light and shade }\end{array}$ & $\begin{array}{l}\text { 1.d An element of theatricality is added through the shades of white } \\
\text { and black. All strips are illustrated in the same way. }\end{array}$ \\
\hline & $\begin{array}{l}\text { 2.Use of } \\
\text { colloquialism } \\
\text { a. Use of Bangla } \\
\text { expletives to } \\
\text { evoke laughter } \\
\text { (shortcut) } \\
\text { b. Bilingualism }\end{array}$ & $\begin{array}{l}\text { 2. Bangla dialect seen through the words, 'pola'(77); ganjacche }(89) \\
\text { 2a. Hotocchara ; dhuttori (81) Bengali expletives but used with an } \\
\text { intent to evoke laughter; hotochhara, garol (91); hotobhaga; morkot; } \\
\text { hotochhara ( } 98) \\
\text { 2b. ghabhrao mat (do not get worried). Combination of Bangla and } \\
\text { English.(79); radio shonar dafa gaya (Bangla and English) (85); bhonda } \\
\text { and his party(88) }\end{array}$ \\
\hline $\begin{array}{l}\text { Speech } \\
\text { balloon }\end{array}$ & $\begin{array}{l}\text { Square with } \\
\text { rounded edges }\end{array}$ & \\
\hline $\begin{array}{l}\text { Colours } \\
\text { used }\end{array}$ & $\begin{array}{l}\text { Bi-colour (Black } \\
\text { and white) }\end{array}$ & Behind the screen dialogue (Aside) (75) \\
\hline $\begin{array}{c}\text { Rhetorical } \\
\text { devices }\end{array}$ & $\begin{array}{l}\text { 1.Regional } \\
\text { Onomatopoeia }\end{array}$ & 1. Khochmoch (87); chorat (93); g-r-r-r-r (94) \\
\hline
\end{tabular}




\begin{tabular}{|c|c|c|}
\hline & $\begin{array}{l}\text { 2. Stuttering } \\
\text { (88) }\end{array}$ & $\begin{array}{l}\text { Hush-h-h-h-h-h (water splashing)(83); sush-h-h-h-h-h (rocket take } \\
\text { off)(88); } \\
\text { 2. tu-lchhi pi-pisemosai (88) }\end{array}$ \\
\hline \multicolumn{3}{|r|}{ Text 3: Nonte Phonte } \\
\hline Stylistics & Characteristics & Excerpts with page numbers \\
\hline Characters & $\begin{array}{l}\text { Nonte has } \\
\text { longer hair with } \\
\text { a hair tuft } \\
\text { sticking out ; } \\
\text { Phonte has } \\
\text { shorter crew- } \\
\text { cut hair }\end{array}$ & $\begin{array}{l}\text { They are always into mischief and either win a situation and get } \\
\text { humiliated. }\end{array}$ \\
\hline Panel/Frame & $\begin{array}{l}\text { Mostly 2. Rarely } \\
3 .\end{array}$ & Remains the same \\
\hline \multirow[t]{2}{*}{ Tone } & $\begin{array}{l}\text { 1.Theatricality } \\
\text { by even use of } \\
\text { light and shade }\end{array}$ & $\begin{array}{l}\text { An element of theatricality is added through the shades of white and } \\
\text { black. All strips are illustrated in the same way. }\end{array}$ \\
\hline & $\begin{array}{l}\text { 2.Use of } \\
\text { colloquialism } \\
\text { a. Use of Bangla } \\
\text { expletives to } \\
\text { evoke laughter } \\
\text { (shortcut) } \\
\text { b. Bilingualism }\end{array}$ & $\begin{array}{l}\text { 2. Baatlechhis(103); chhonra (103); morchhish (111); moreche (120); } \\
\text { phasaade (120); saabre; shokunimarka (121) } \\
\text { 2a. Chhuncho (104); hotochhara (105; 118); cheatingbaaj (118); morkot } \\
\text { (118); chhinchke (122) } \\
\text { 2b. shortcut; tight (103); paakrao kor (122) }\end{array}$ \\
\hline $\begin{array}{l}\text { Speech } \\
\text { balloon }\end{array}$ & $\begin{array}{l}\text { Spherical } \\
\text { shaped; square } \\
\text { with rounded } \\
\text { edges }\end{array}$ & ; \\
\hline $\begin{array}{l}\text { Colours } \\
\text { used }\end{array}$ & $\begin{array}{l}\text { Bi-colour; Black } \\
\text { and white ; red } \\
\text { and black }\end{array}$ & \\
\hline $\begin{array}{l}\text { Rhetorical } \\
\text { devices }\end{array}$ & $\begin{array}{l}\text { 1.Regional } \\
\text { Onomatopoeia } \\
\text { 2. Stuttering } \\
(88)\end{array}$ & $\begin{array}{l}\text { 1. Jhappashhhh (falling into a water pool) (104); aafff, uffff (caned } \\
\text { by school teacher) (105); fararrrrrr phonth (snoring)(107); hank } \\
\text { pank (115); honkshhh (dashing against teacher(122) } \\
\text { 2. Ki-ki-kintu (122) }\end{array}$ \\
\hline
\end{tabular}

